\title{
Solid-State Ionic Liquid Based Electrolytes for Dye-Sensitized Solar Cells
}

\author{
Chuan-Pei Lee, Te-Chun Chu, Ling-Yu Chang, \\ Jiang-Jen Lin and Kuo-Chuan Ho \\ Additional information is available at the end of the chapter \\ http://dx.doi.org/10.5772/53647
}

\section{Introduction}

\subsection{Dye-sensitized solar cells (DSSCs)}

The increasing global need for energy coupled with the depletion of easily accessible, hence cheap, fossil fuel reserves, poses a serious threat to the human global economy in the near future [1]. Considering in addition the harmful ecological impact of conventional energy sources, it becomes obvious that development of clean alternative energy sources is a necessity $[2,3]$. Best renewable energy options must rely on a reliable input of energy onto the earth. Since the sun is our only external energy source, harnessing its energy, which is clean, non-hazardous and infinite, satisfies the main objectives of all alternative energy strategies. Mastering the conversion of sunlight to electricity or to a nonfossil fuel like hydrogen is without any doubt the most promising solution to the energy challenge. It is remarkable that a mere 10 min of solar irradiation onto the Earth's surface is equal to the total yearly human energy consumption [4]. Therefore, solar power is considered to be one of the best sustainable energies for future generations. To date photovoltaics has been dominated by solid-state junction devices, usually in silicon, crystalline or amorphous, and profiting from the experience and materials availability resulting from the semiconductor industry. However, the expensive and energy-intensive high-temperature and high-vacuum processes is needed for the silicon based solar cells. Therefore, the dominance of the photovoltatic field by such kind of inorganic solid-state junction devices is now being challenged by the emergence of a third generation solar cell based on interpenetrating network structures, such as dye-sensitized solar cells (DSSCs) [5]. 
Since Professor M. Grätzel in EPFL introduced the nanoporous films into dye-derived wideband semiconductor research and made the breakthrough in the photoelectric conversion efficiency of DSSCs, academic and commercial interests have been focused on DSSCs for their high efficiency, potential low-cost and simple assembly technology. This became especially noticeable when the first cell with a certified efficiency of greater than $10 \%$ was demonstrated [6-10]. By incorporating the novel YD2-o-C8 dye and cosensitizing with Y123 dye, the DSSC with a traditional liquid electrolyte has achieved a $12.3 \%$ efficiency record [11], encouraging the surge to explore new organic materials for the conversion of solar to electric power.

The DSSC device is composed of three adjacent thin layers such as a high band-gap nanocrystalline semiconductor-based mesoporous film adsorbed with a dye sensitizer on the working electrode for the absorption in the visible region, a platinized counter electrode for the collection of electrons and a redox electrolyte, sandwiched between the two electrodes. The usual choice for the semiconductor material is titanium dioxide $\left(\mathrm{TiO}_{2}\right)$, whereas ruthenium bipyridyl derivatives (N3, N719, Z907 and black dye etc.) are for the dye sensitizer. The electrolyte mostly contains $\mathrm{I}^{-} / \mathrm{I}_{3}{ }^{-}$redox couple, which was obtained by the mixing of iodine $\left(\mathrm{I}_{2}\right)$ and inorganic or organic iodides in suitable non-aqueous solvents. Upon absorption of light, an electron is injected from a metal-to-ligand charge transfer excited state of the dye into the conduction band of the metal oxide. The rate of this electron injection reaction is ultrafast, typically occurring on the order of hundreds of femtoseconds to tens of picoseconds. The injected electron percolates through the $\mathrm{TiO}_{2}$ film, and is thought to move by a "hopping" mechanism and is driven by a chemical diffusion gradient (rather than an electric field), and is collected at a transparent conductive substrate of fluorine doped tin oxide glass $\left(\mathrm{SnO}_{2}: \mathrm{F}\right)$, on which the $\mathrm{TiO}_{2}$ film is formed. After passing through an external circuit, the electron is reintroduced into the solar cell at the platinum counter electrode, where triiodide is reduced to iodide. The iodide then regenerates the oxidized dye, thereby completing the circuit with no net chemical change.

\subsection{Ionic liquids (ILs)}

Ionic liquids (ILs) are low-temperature molten salts with melting points below $100{ }^{\circ} \mathrm{C}$, that is, liquids composed of ions only. The salts are characterized by weak interactions, owing to the combination of a large cation and a charge-delocalized anion. This results in a low tendency to crystallize due to flexibility (anion) and dissymmetry (cation). ILs are basically composed of organic ions that may undergo almost unlimited structural variations because of the easy preparation of a large variety of their components. Thus, various kinds of salts can be used to design the ionic liquid that has the desired properties for a given application. These include, among others, imidazolium, pyrrolidinium and quaternary ammonium salts as cations and bis(trifluoromethanesulphonyl)imide, bis(fluorosulphonyl) imide and hexafluorophosphate as anions.

An IL, triethylammonium nitrate (a pure low-melting salt), was firstly identified more than a century ago. In the 1930s, a patent application described cellulose dissolution using a molten pyridinium salt above $130{ }^{\circ} \mathrm{C}$. It was the need for a sturdy medium for nuclear fuel re- 
processing that prompted the study of low-melting-point chloroaluminates. Among the onium cations with positive nitrogen(s), those derived from the imidazolium ring proved to be the best choice in terms of melting points and electrochemical stability [12]. At the same time, the need for new anions for organic polymer electrolytes based on polyethylene oxide led to the concept of a plasticizing anion, that is, an anion having a delocalized charge and multiple conformations differing only marginally in energy. The archetype of such anions is the bis(trifluoromethylsulphonyl) amide $\left(\mathrm{CF}_{3} \mathrm{SO}_{2}-\mathrm{N}-\mathrm{SO}_{2} \mathrm{CF}_{3}\right)$ ion, also known as $\mathrm{NTf}_{2}$, in which the extremely electron-withdrawing $\mathrm{CF}_{3} \mathrm{SO}_{2}$-groups are conjugated and linked by flexible S-N-S bonds. When combined with an imidazolium cation, such as the ethylmethylimidazolium cation, this anion produces a fluid IL (melting point: $-15{ }^{\circ} \mathrm{C}$ ) with an ion conductivity comparable to that of the best organic electrolyte solutions; it shows no vapour pressure or no decomposition up to $\sim 300-400{ }^{\circ} \mathrm{C}$ [13]. It is not miscible with water $(\sim 1,000$ p.p.m. in equilibrium with liquid $\mathrm{H}_{2} \mathrm{O}$ ), and thus defies the conventional wisdom that states polarity is synonymous with hydrophilicity. ILs then developed rapidly, with a reinvestigation of ions, for example quaternary ammonium cations, that had been avoided previously by organic chemists because of unsymmetrical shapes that hindered easy purification through crystallization. The organic chemistry community had earlier engaged in research of media with controllable Lewis acidity (chloroaluminate ILs), but the modern era of ILs has produced numerous neutral ILs, that is, those based on ions which are unreactive towards acids or bases, be they Lewis or Bronsted. As a result, it is now difficult to name an organic reaction that has not been performed successfully in these potentially green solvents, which can be recycled almost indefinitely with no or minimal use of volatile organic compounds. Most products made in ILs can be distilled off, in the case of small molecules, or extracted with water or hydrocarbon solvents, at least one of which is usually immiscible with the ionic liquid.

It is this unique solvent potential that makes ILs key materials for the development of a range of emerging technologies. The advent of ILs has made viable processes that fail, or are even impossible, with conventional solvents. Water sensitive metals or semiconductors that previously could not be deposited from conventional water baths can now, by turning to ILs, be directly electroplated. Energy devices, such as the quasi-solid/all-solid-state DSSCs, polymer-electrolyte-membrane fuel cells, lithium batteries and supercapacitors presently under development to address the challenges of increasing energy costs and global warming, may greatly benefit from a switch to low-vapour-pressure, non-flammable, ILs-based electrolytes.

\subsection{ILs as the electrolyte for DSSCs}

The role of the electrolyte in DSSCs is very important as it provides the necessary ionic conductivity in the bulk of the solution and sets the potential barrier necessary for the energy conversion. In addition, it offers a reduction reaction at the counter electrode and helps for the dye regeneration by the charge-transfer reaction with the dye molecule [14]. Usually, the conventional inorganic and organic iodide electrolyte salts are lithium and tetra-alkyl ammonium iodides, respectively. Besides this, several molten salts, particularly ionic liquid 
based imidazolinium salts, have also been used for improving the performance of the DSSCs [15-19]. In these works, cations play an important role in determining the conversion efficiency of the DSSCs. For example, the interaction of $\mathrm{Li}^{+}$with $\mathrm{TiO}_{2}$ enhances the electron transfer from the sensitized dye to the $\mathrm{TiO}_{2}$ and from $\mathrm{I}^{-}$to the oxidized dye, leading to high photocurrent [20-22]. In the case of imidazolinium cations, the increase in the concentration of imidazolinium cations leads to the decrease of recombination at the working electrode due to the multilayer adsorption; thus improving the DSSC performance [23]. Kubo et al. [15] further studied the effect of the alkyl chain length of some imidazolium cations on the electron recombination lifetime. They found that the chain length does affect the electron recombination lifetime. The lifetime increased with the increase in the alkyl chain length. This is because hydrophobic alkyl chains may impede $\mathrm{I}_{3}^{-}$from reaching $\mathrm{TiO}_{2}$. The result reveals that bigger cations may enhance photocurrent due to the lower probability of electron recombination.

The highest efficiency record of DSSC was obtained based on the highly volatile organic solvent electrolyte due to the efficient infiltration of organic electrolyte in nanocrystalline films. However, commercialization of the cells with organic liquid electrolytes was impeded owing to technological problems related to hermetic sealing, precipitation of salts at low temperature and evaporation of liquids at high temperature; long-term stability is thus a major problem for these types of cells. Therefore, p-type inorganic semiconductors [24-26], organic hole conducting materials [27-30], ionic gel electrolytes having a polymer or a gelator [15, 31-33], and ionic liquid (IL) based electrolytes (or IL based electrolyte containing dispersed nano-components) $[18,34-40]$ were recently investigated for preparing the electrolytes. In these cases, imperfect filling of the dye-coated porous $\mathrm{TiO}_{2}$ film by p-type inorganic semiconductors or polymers has resulted in poor efficiency for the cells. Another weakness of the inorganic p-type materials is the decided chemical structure, resulting in the limitedly adjustable chemical/physical properties in the application of solid-state electrolytes. Meanwhile, the inorganic p-type material derived all-solid-state DSSCs shows no stability. This should be ascribed to inorganic p-type materials tending to be oxidized under continuous illumination and the worsening of the interfacial contact between dye-sensitized $\mathrm{TiO}_{2}$ and electrolyte along with the growth of age [41]. Moreover, the carrier diffusion length was limited in the case of conducting polymers due to their low conductivity. Thereby, ILs based electrolytes were considered to be most attractive for replacing the organic solvents; they are preferred because of their negligible vapor pressure, high thermal stability, wide electrochemical window, and high ionic conductivity [42-46]. However, most ILs based electrolytes are liquid at room temperature [36, 43, 45-48]. Therefore, the fluidity and potential leakage of ILs based electrolytes during long-term operation is still unavoidable, which limits their wide application in DSSCs. To overcome this problem, the solid-state ILs have been applied as solid-state electrolytes for DSSCs recently.

This chapter mainly reviewed the recent researches on the topic of solid-state ILs-based electrolytes for DSSCs. Here the solid-state ILs employed in the electrolytes of DSSCs can be classified as follows: (a) ILs crystals (system A), (b) ILs polymers (system B), and (c) ILs conductors (system C). 


\section{Solid-state ILs-based electrolytes for DSSCs}

\subsection{ILs crystals (system A)}

In year 2005, Yamanaka et al. [49] reported a new strategy for enhancing the conductivity of ILs based electrolytes; employing an IL crystal as a constituent of an electrolyte, which forms a self-assembled structure and promotes the exchange reaction by the locally increased concentrations of $\mathrm{I}_{2}$ and $\mathrm{I}_{3}^{-}[15,50]$. They selected 1-dodecyl-3-methylimidazolium iodide (C12MImI) as the IL crystal. This provides a self-assembled structure of the imidazolium cations like a solid, while maintaining the molecular dynamics like a liquid. The IL crystal (C12MImI) with the smectic A phase (SA) has a bilayer structure of interdigitated alkyl chains of the imidazolium cations, and $\mathrm{I}_{2}$ and $\mathrm{I}_{3}{ }^{-}$would be localized between the SA layers. The locally high concentration would promote the exchange reaction. So, the IL crystal with the SA phase would be suitable for the electrolyte of DSSC. A few examples of the IL crystal with the SA phase, such as imidazolium salts consisting of cations with alkyl chains of C12-C18 and anions of hexafluorophosphate or bromide, have been reported [51, 52]. Before their study [49], an imidazolium salt with iodide as the counter anion has not been reported to be an IL crystal with a SA phase. Therefore, they showed for the first time that imidazolium iodides with alkyl chains longer than C12 exhibit a SA phase and that the liquid crystalline nature is preferable in terms of the hole transport layer in DSSC. The DSSC with $\mathrm{C} 12 \mathrm{MImI} / \mathrm{I}_{2}$ electrolyte achieved a cell efficiency $(\eta)$ of $2.30 \%$ under AM 1.5 irradiation. Zhao et al. [53] reported a solid-state DSSC utilizing imidazolium-type ionic crystal (1-methyl-3-hydroxyethyl-imidazolium iodide, $\mathrm{MH}-\mathrm{II}$ ) as the charge transfer layer, and obtained a good cell efficiency of $3.10 \%$ under one sun irradiation by adopting 1-methyl-3-propylimidazolium tetra-fluoroborate $\left(\mathrm{MP}^{-} \mathrm{BF}_{4}\right)$ as a crystal growth inhibitor, lithium bis-trifluoromethanesulfonylimideas $\left(\mathrm{Li}\left[\left(\mathrm{CF}_{3} \mathrm{SO}_{2}\right)_{2} \mathrm{~N}\right]\right)$ a charge transport enhancer, and 4-tertbutylpyridine (tBP) as a carrier recombination inhibitor. As shown in their report, the cell efficiency remained $60 \%$ of the initial value after 30 days at room temperature (R. T.) without any sealing and protection from ambient condition. Lee et al. [54] have fabricated all-solid-state DSSCs with a hybrid SWCNT-binary charge transfer intermediate (CTI), consisting of single wall carbon nanotubes (SWCNT), 1-ethyl-3-methylimidazolium iodide (EMII) and 1-methyl-3-propyl imidazolium iodide (PMII), without the addition of $\mathrm{I}_{2}$ and $\mathrm{tBP}$. A solid organic ionic crystal, EMII, was employed as CTI to fabricate all-solid-state DSSCs. In addition, SWCNTs were incorporated into the CTI as the extended electron transfer materials (EETM), which can reduce charge diffusion length and serve simultaneously as catalyst for the electrochemical reduction of $\mathrm{I}_{3}{ }^{-}$. An all-solid-state DSSC with this hybrid SWCNT-EMII achieved the higher cell efficiency $(1.88 \%)$, as compared to that containing bare EMII $(0.41 \%)$. To further improve the cell efficiency, they utilized PMII, which acts simultaneously as a co-charge transfer intermediate and crystal growth inhibitor. The highest cell efficiency $(3.49 \%)$ was obtained using a hybrid SWCNT-binary CTI. In their studies, the durability of the solid-state DSSCs were studied at R. T. and was found to be far superior to that of a cell with an organic solvent electrolyte. In their further study, Lee et al. [55] also developed a solid-state composite electrolyte, comprising two ionic liquids and a carbon material, to fab- 
ricate a solid-state DSSC; the ILs were EMII and 1-ethyl-3-methylimidazolium tetrafluoroborate $\left(\mathrm{EMIBF}_{4}\right)$, and the carbon materials were carbon black $(\mathrm{CB})$, multi-wall carbon nanotubes (MWCNT), and single-wall carbon nanotubes (SWCNT). A cell efficiency of $0.41 \%$ was achieved by using the bare EMII as the CTI; an efficiency of $2.52 \%$ was achieved for a solid-state DSSC by the incorporation of carbon black (CB) in the EMII. To further improve the cell efficiency, they utilized $\mathrm{EMIBF}_{4}$, a crystal growth inhibitor, as an additive to the electrolyte. A cell efficiency of 3.09\% was obtained using an electrolyte conaining the CB and the binary CTI (EMII plus $\mathrm{EMIBF}_{4}$ ). When the CB was replaced with MWCNT and SWCNT, the cell efficiency could be improved to $3.53 \%$ and $4.01 \%$, respectively. Long-term durability of the DSSC with SWCNT-binary CTI was found to be far superior to that of the cell with an organic solvent electrolyte, and in fact the durability was uninterrupted for at least 1,000 h. Armel et al. [56] have develpoed the organic ionic plastic crystals as a new class of solid-state electrolyte for DSSCs. The DSSC with their solid-state electrolyte, containing N,N-dimethylpyrrolidinium dicyanamide $\left(\mathrm{C}_{1} \operatorname{mpyrN}(\mathrm{CN})_{2}\right)$, EMII, lithium iodide (LiI), $\mathrm{I}_{2}$ and $\mathrm{N}$-methylbenzimidazole (NMB), achieved a good cell efficiency of $5.10 \%$ under the illumination of 1 sun (AM 1.5G). Among the system A, Chen et al. [57] have developed a most efficient solid-state electrolyte employing an ionic liquid (1, 2-dimethyl-3-propylimidazolium iodide, DMPII) as CTI for DSSCs. Simultaneously, potassium iodide (KI) and polyethylene oxide (PEO, MW = 100,000) were incorporated into the CTI as the charge transfer auxiliary agent and the crystal growth inhibitor, respectively. Where, the strong interactions between the potassium cations and PEO can prevent the crystallization of the CTI and then enhance its ionic conductivity. As shown in Figure 1, an optimal cell efficiency of $5.87 \%$ can be obtained for the DSSC fabricated with the solid-state electrolyte of DMPII/KI/PEO. The corresponding photovoltaic parameters of the DSSCs with their solid-state electrolyte containing different KI contents are listed in Table 1. Recently, Li et al. [58] also reported the development of organic ionic plastic crystals, instead of molecular plastic crystals (such as succinonitrile), as the electrolytes for solid-state DSSCs. Compared with molecular plastic crystals, the advantages of ionic plastic crystal materials are their higher conductivity and very low volatility [59]. In their work, 1-ethyl-1-methylpyrrolidinium bis(tri-fluoromethane sulfonyl)imide ( $\mathrm{P}_{12} \mathrm{TFSI}$ ), a well-known example of an organic ionic plastic crystal [40, 60-62], which shows a broad solid-solid transformation at $14^{\circ} \mathrm{C}$ (entropy of transition $3.1 \mathrm{~J}$ $\mathrm{K}^{-1} \mathrm{~mol}^{-1}$ ) and a melting point at $86{ }^{\circ} \mathrm{C}$, was applied as the electrolyte for solid-state DSSCs. A room-temperature (R.T.) IL, PMII, was used as the iodide source for the electrolyte. The DSSCs with $\mathrm{P}_{12}$ TFSI/PMII electrolyte yielded a cell efficiency of 3.92\% under the illumination of $100 \mathrm{~mW} \mathrm{~cm}^{-2}$ (AM 1.5G). Further addition of LiI and N-butylbenzimidazole (NBB) to the $\mathrm{P}_{12}$ TFSI/PMII electrolyte improved the cell efficiency to $4.78 \%$. Their DSSCs, using $\mathrm{P}_{12} \mathrm{TFSI} /$ PMII/LiI/NBB electrolyte, displayed better long-term stability compared to conventional liquid electrolytes, and remained $90 \%$ of the initial value after 50 days under ambient conditions without further sealing. Cao-Cen et al. [63] have synthesized the organic ionic crystal (N-4-(4-cyanobiphenyl-40-oxy)-butyl-3-butylimidazolium bromide, $\mathrm{C}_{4} \mathrm{BImBr}$ ) carrying 4-cyano-4'-hydroxybiphenyl and imidazolium units and applied them as the electrolytes for DSSCs. It has been demonstrated that biphenyl and 4-cyanobiphenyl are important core units for mesogenic molecules [64-67]. Cyanobiphenyl-functionalized compounds can act as 
a kind of low light-transmitting and high light-scattering material and obtained a high lightharvesting efficiency when they were employed as an electrolyte placed at the back of the working electrode of DSSC. The fabricated all-solid-state DSSCs with EMII $/ \mathrm{I}_{2} / \mathrm{C}_{4} \mathrm{BImBr}$ electrolyte achieved a good cell efficiency of $4.45 \%$ under the illumination of $100 \mathrm{~mW} \mathrm{~cm}{ }^{-2}$ (AM $1.5 \mathrm{G})$ because of the enhanced light harvesting capability of the electrolyte containing $\mathrm{C}_{4} \mathrm{BImBr}$. To further improved the cell efficiency, PMII, was added into the EMII/ $\mathrm{I}_{2} / \mathrm{C}_{4} \mathrm{BImBr}$ electrolyte as a crystal growth inhibitor. This fabricated DSSC with EMII/ $/ 2 / \mathrm{C}_{4} \mathrm{BImBr} / \mathrm{PMII}$ electrolyte showed an enhanced cell efficiency of 5.07\% under the illumination of $100 \mathrm{~mW}$ $\mathrm{cm}^{-2}$ (AM 1.5G), and it also possessed a good long-term stability (decay 5\%) for 1,000 h during the accelerated aging test (1sun light soaking) at $25^{\circ} \mathrm{C}$.

Table 2 is a partial list of the all-solid-state DSSCs with ILs crystals-based electrolytes, which were obtained from the literatures.

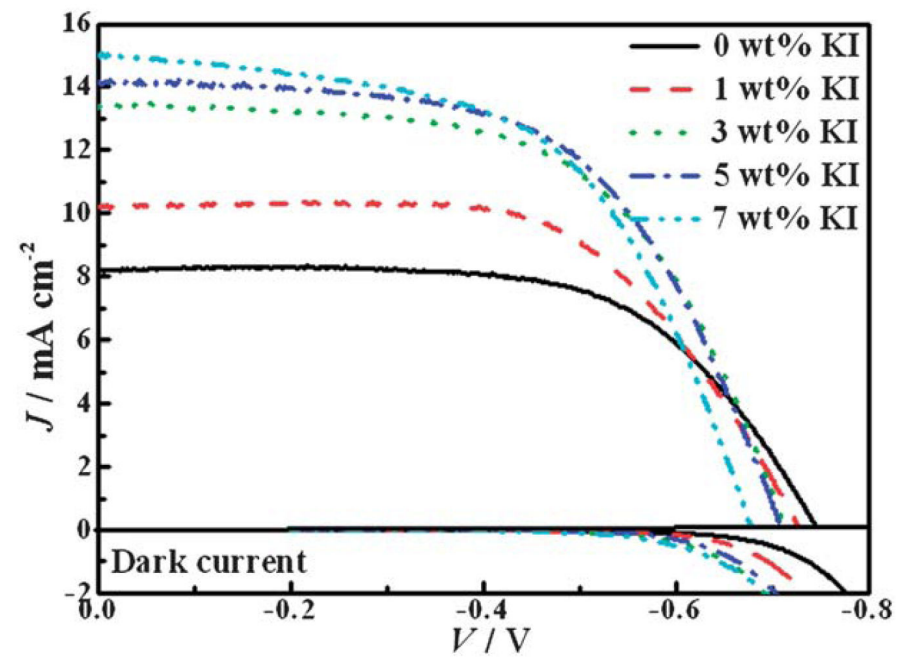

Figure 1. Photovoltaic characteristics of DSSCs assembled with the quasi solid-state electrolyte containing different $\mathrm{KI}$ contents under $100 \mathrm{~mW} \mathrm{~cm}^{-2}$ and in the dark [57].

\begin{tabular}{ccccc}
\hline KI (wt\%) & $\boldsymbol{J}_{s c}\left(\boldsymbol{m A ~ c m}{ }^{-2}\right)$ & $\boldsymbol{V}_{\text {oc }}(\boldsymbol{m V})$ & $\boldsymbol{F F}$ & $\boldsymbol{\eta}(\%)$ \\
\hline 0 & 8.22 & 750 & 0.65 & 4.05 \\
\hline 1 & 10.21 & 730 & 0.61 & 4.56 \\
\hline 3 & 13.44 & 710 & 0.59 & 5.66 \\
\hline 5 & 14.11 & 710 & 0.59 & 5.87 \\
\hline 7 & 15.00 & 680 & 0.56 & 5.72 \\
\hline
\end{tabular}

Table 1. Photovoltaic characteristics of DSSCs assembled with the quasi solid-state electrolytes containing different KI contents under $100 \mathrm{~mW} \mathrm{~cm}^{-2}$. 


\begin{tabular}{|c|c|c|c|c|c|c|c|c|c|}
\hline References & ILs crystals & Structures & Electrolytes & Dye & $\begin{array}{c}J_{S C} \\
(m A \\
\left.c m^{-2}\right)\end{array}$ & $V_{O C}(m V)$ & $F F$ & $\eta(\%)$ & Durability \\
\hline $\begin{array}{c}\text { Yamanaka et } \\
\text { al., (2005) }\end{array}$ & C12MIml & 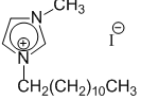 & C12Mlml; I & N. A. & $\sim 7.00$ & $\sim 520$ & $\sim 0.63$ & $\sim 2.30$ & N. A. \\
\hline $\begin{array}{c}\text { Zhao et al., } \\
\text { (2008) }\end{array}$ & $\mathrm{MH}-\mathrm{II}$ & $\mathrm{CH}_{3}$ & $\begin{array}{c}\mathrm{MH}-\mathrm{Il} ; \\
\mathrm{MP}-\mathrm{BF}_{4 i} \\
\mathrm{Li}\left[\left(\mathrm{CF}_{3} \mathrm{SO}_{2}\right)_{2} \mathrm{~N}\right] \\
; \mathrm{tBP}\end{array}$ & N3 & 7.01 & 646 & 0.69 & 3.10 & $\begin{array}{c}30 \text { days } \\
\text { at-rest at } 25^{\circ} \mathrm{C} \text {, } \\
\text { decay } 40 \%\end{array}$ \\
\hline $\begin{array}{l}\text { Lee et al., } \\
(2010)\end{array}$ & & $\mathrm{CH}_{3}$ & $\begin{array}{c}\text { EMIl; PMIl; } \\
\text { SWCNTs }\end{array}$ & & 8.07 & 716 & 0.61 & 3.49 & $\begin{array}{c}1,000 \mathrm{~h} \\
\text { at-rest at } 25^{\circ} \mathrm{C}, \\
\text { no decay }\end{array}$ \\
\hline $\begin{array}{l}\text { Lee et al., } \\
\text { (2011) }\end{array}$ & & $\mathrm{CH}_{3}$ & $\begin{array}{c}\text { EMII; EMIBF }_{4} ; \\
\text { SWCNTs }\end{array}$ & & 9.74 & 620 & 0.66 & 4.01 & $\begin{array}{c}1,000 \mathrm{~h} \\
\text { at-rest at } 25^{\circ} \mathrm{C}, \\
\text { no decay }\end{array}$ \\
\hline
\end{tabular}
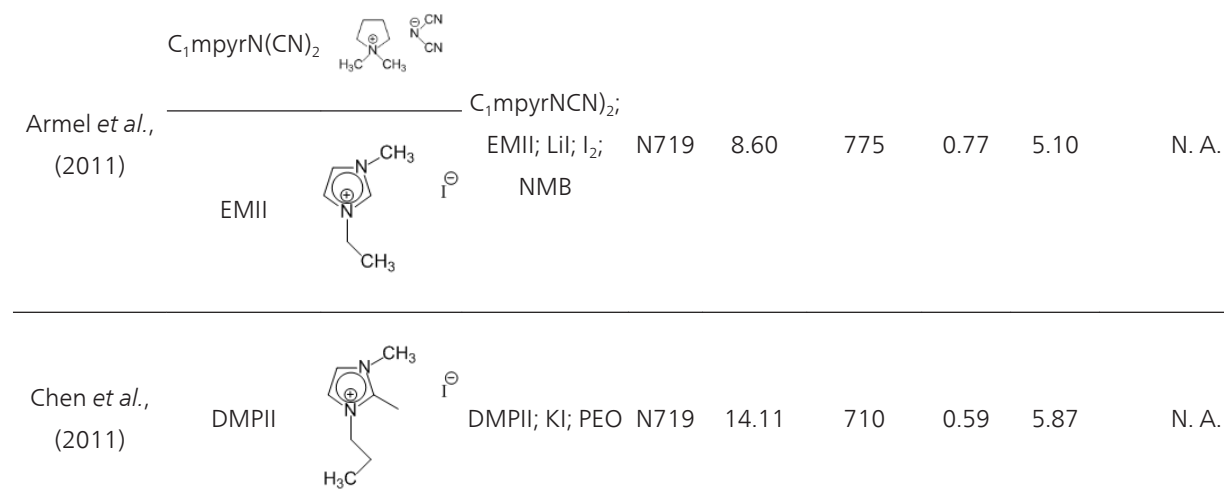

\begin{tabular}{|c|c|c|c|c|c|c|c|c|c|}
\hline $\begin{array}{l}\text { Li et al., } \\
(2012)\end{array}$ & $\mathrm{P}_{12} \mathrm{TFSI}$ & 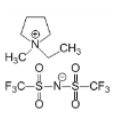 & $\begin{array}{c}\text { P }_{12} \text { TFSI; PMII; } \\
\text { Lil; NBB }\end{array}$ & Z907 & 12.45 & 588 & 0.65 & 4.78 & $\begin{array}{c}50 \text { days } \\
\text { at-rest at } 25^{\circ} \mathrm{C} \text {, } \\
\text { decay } 10 \%\end{array}$ \\
\hline $\begin{array}{l}\text { Cao-Cen et } \\
\text { al., (2012) }\end{array}$ & $\mathrm{C}_{4} \mathrm{BImBr}$ & & $\begin{array}{c}\text { EMII; } \mathrm{I}_{2} \\
\mathrm{C}_{4} \mathrm{BImBr} ; \mathrm{PMII}\end{array}$ & Z907 & 12.39 & 609 & 0.67 & 5.07 & $\begin{array}{c}1,000 \mathrm{~h} \\
\text { light soaking at } \\
25^{\circ} \mathrm{C} \text {, decay } 5 \%\end{array}$ \\
\hline
\end{tabular}

Table 2. Partial literatures reported on the solid-state DSSCs with ILs crystals. 


\subsection{ILs polymers (system B)}

Wang et al. [68, 69] have synthesized the IL polymers, poly (1-alkyl-3-(acryloyloxy)hexylimidazolium iodide) (PAAII) and employed it as an iodine-free electrolyte for all-solid-state DSSCs. PAAII is an ionic liquid polymer formed from the polymerization of monomers containing IL moieties [70, 71]. IL polymers contain both the IL structure and the polymer main chain. They show good ionic conductivity without liquid components due to their specific functions such as transport of target ions, specific polar environment and mechanical strength [72]. They used poly (1-ethyl-3-(acryloyloxy)hexylimidazolium iodide) (PEAII) as the electrolyte without the addition of iodine, a cell efficiency of $5.29 \%$ has been achieved in solid-state DSSCs under illumination of $100 \mathrm{~mW} \mathrm{~cm} \mathrm{~cm}^{-2}$ (AM 1.5G). PEAII also exhibited high thermal stability, and the DSSC assembled with PEAII electrolyte maintained about $85 \%$ of their initial efficiency after 1,000 h without sealing. An acidic ionic liquid polymer P [((3-(4vinylpyridine) propanesulfonic acid) iodide)-co-(acrylonitrile)], which is named as P-HI for short, has been synthesized and employed in ILs electrolyte for DSSCs by Fang et al. [73]. The polymer P-HI contains sulfonic acid group, which has electrostatic forces with ILs to form the homogeneous and continuous framework for enhancing transportationof redox couples in the electrolyte. The DSSC with the novel ILs electrolyte, containing P-HI, NMB, guanidinium thiocyanate (GuNCS), 1-hexyl-3-methylimidazolium iodide (HMII) and 1-allyl-3-methylimidazoliumiodide (AMII), achieved the highest cell efficiency of $6.95 \%$ under AM 1.5G illumination at $100 \mathrm{~mW} \mathrm{~cm}^{-2}$ in the system B. They also investigated the effects of the concentration of iodine on the performance of DSSCs with their electrolyte system. As shown in Figure 2, they found that the addition of iodine mainly reduces the open-circuit voltage $\left(V_{\mathrm{OC}}\right)$ and slightly decreases the short-circuit current density $\left(J_{\mathrm{SC}}\right)$ of their cells due to the increase in dark current and the serious visible light by $\mathrm{I}_{3}^{-}$, respectively. Therefore, they demonstrated that their system works best without the addition of iodine. Chi et al. [74] have synthesized a polymerized ionic liquid of poly((1-(4-ethenylphenyl)methyl)-3-butylimidazolium iodide) (PEBII) and employed it as a solid electrolyte for $\mathrm{I}_{2}$-free solid-state DSSCs. In their study, the photoanode/electrolyte interfaces were significantly improved using a graft copolymer-directed and organized mesoporous $\mathrm{TiO}_{2}$ thin film. The cell efficiency of the DSSC with PEBII has reached 5.93\% at $100 \mathrm{~mW} \mathrm{~cm}^{-2}$. In their further study [75], they utilized a novel $\mathrm{TiO}_{2}$ photoanode with double layer structures containing mesoporous $\mathrm{TiO}_{2}$ beads and PEBII electrolyte for constructing an solid-state DSSC; the cell efficiency was then enhanced up to $6.70 \%$. Bis-imidazolium based poly(ionic liquid), poly(1-butyl-3-(1-vinylimidazolium-3-hexyl)-imidazolium bis(trifluoromethanesulfonyl)imide) (Poly[BVIm] [HIm] [TFSI]), was synthesized by Chen et al. [76], and it was dissolved in the ILs electrolyte (EMII/ PMII/1-ethyl-3-methylimidazolium thiocyanate (EMISCN)/ $\mathrm{I}_{2} / \mathrm{GuSCN} / \mathrm{N}$-butylbenzimidazole (NBB)) to form solid-state electrolytes for DSSCs, without using any volatile organic solvent. They found that the bis-imidazolium based Poly[BVIm][HIm][TFSI] electrolyte possessed good thermal stability and conductivity due to the charge transport networks formed in the electrolyte via the $\pi-\pi$ stacked imidazolium rings. The DSSCs based on Poly[BVIm][HIm] [TFSI] electrolyte yielded the cell efficiency of 5.92\% under the simulated AM 1.5G solar

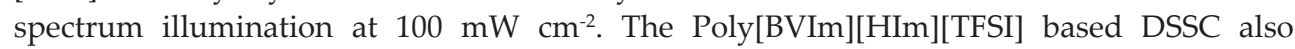
showed a good long-term stability during accelerated aging test under 1 sun light-soaking at 
$60{ }^{\circ} \mathrm{C}$, and it retains about $96 \%$ of the initial efficiency even after about 1,200 $\mathrm{h}$ test. In the recent report from Chang et al. [77], multi-walled carbon nanotubes (MWCNT) coated with a thin layer of 1-(2-acryloyloxy-ethyl)-3-methyl-benzoimidazol-1-ium iodide (AMBImI) were successfully fabricated by physical adsorption. They were then incorporated into poly(1-(2acryloyloxy-ethyl)-3-methyl-imidazol-1-ium iodide (poly(AMImI))-based electrolytes to fabricate an all-solid state DSSC. The DSSC with the solid-state electrolyte,containing, achieved a cell efficiency of $3.55 \%$ at $100 \mathrm{~mW} \mathrm{~cm}^{-2}$.

Table 3 is a partial list of the all-solid-state DSSCs with ILs polymers-based electrolytes, which were obtained from the literatures.

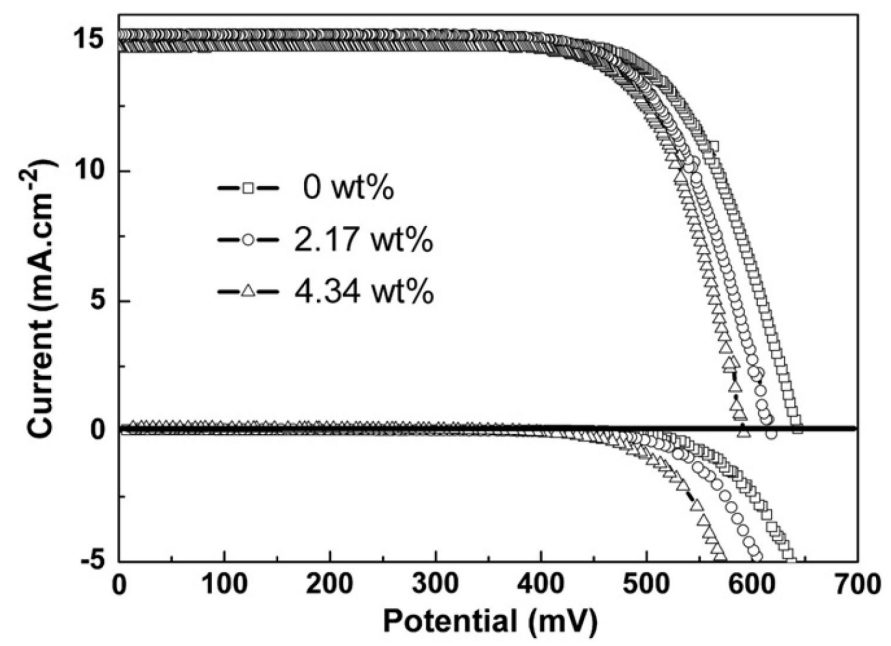

Figure 2. Photovoltaic characteristics of DSSCS using PH-I based electrolyte containing different contents of iodine measured under $100 \mathrm{~mW} \mathrm{~cm}^{-2}$ and in the dark [73]. 


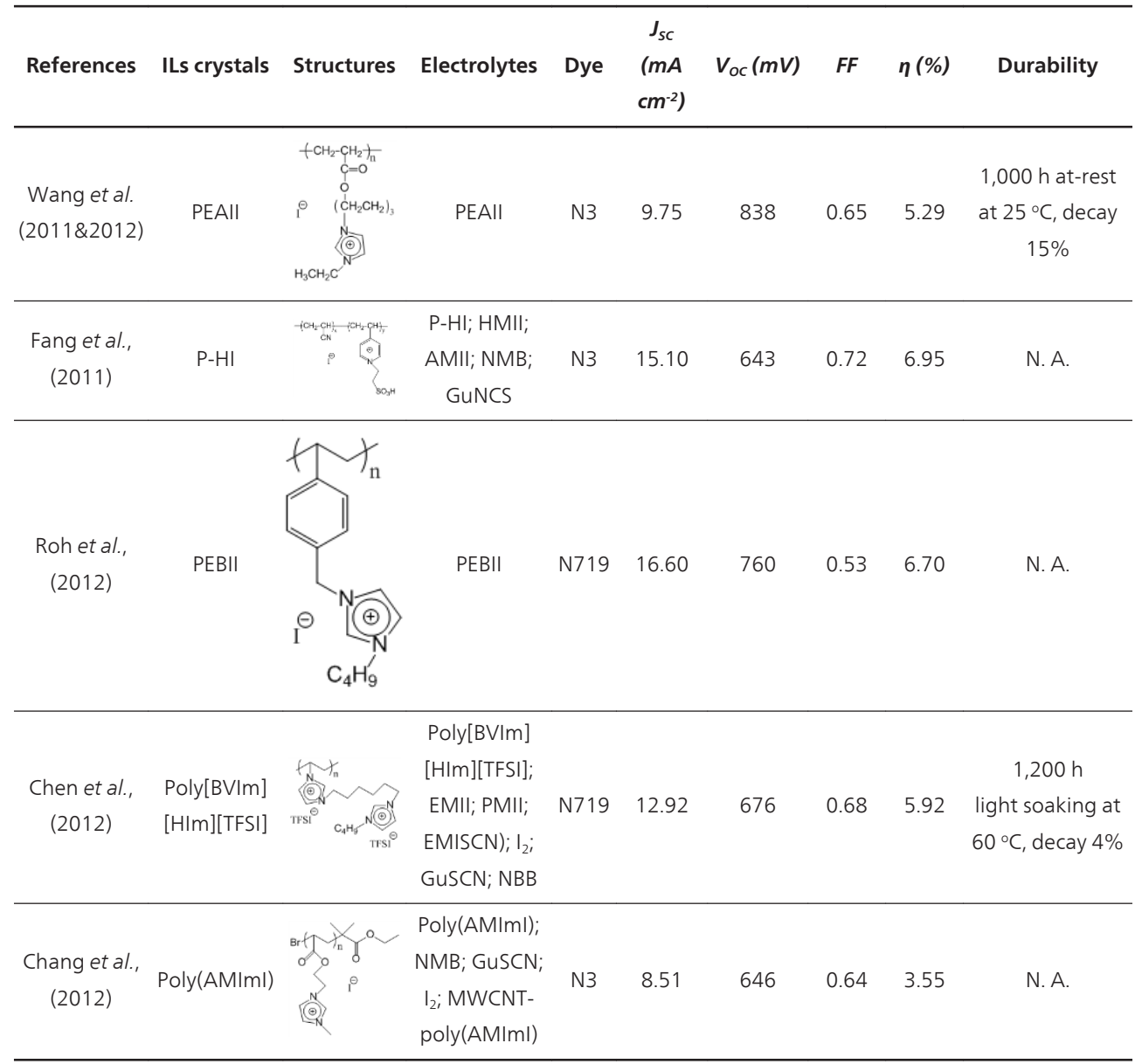

Table 3. Partial literatures reported on the solid-state DSSCs with ILs polymers.

\subsection{ILs conductors (system C)}

Recently, Midya et al. [78] have designed and synthesized a new class of solid-state ionic conductors (Table 4) based on a carbazole-imidazolium ionic salt as electrolytes for solidstate DSSCs. Carbazole is chosen as the hole conductor because polyvinyl carbazole has already been employed successfully in a solid-state DSSC as a hole conductor [79]. In their report [78], the solid-state IL conductors with $\mathrm{SCN}^{-}$anions (SD1) or I' anions (SD2) were synthesized and applied in an all-solid-state DSSC. The solid-state electrolyte containing SD2 and $\mathrm{I}_{2}$ can provide dual channels for hole/triiodide transportation (Figure 3). In their systm (system C), the DSSC with a solid-state electrolyte, containing SD2, $\mathrm{I}_{2}$, $\mathrm{Li}\left[\left(\mathrm{CF}_{3} \mathrm{SO}_{2}\right)_{2} \mathrm{~N}\right], \mathrm{tBP}$ and 1-ethyl-3-methyl-imidazolium tetracyanoborate $\left(\mathrm{EMIB}(\mathrm{CN})_{4}\right)$, ach- 
ieved the highest cell efficiency of $2.85 \%$ under one sun irradiation, and the efficiency of the DSSC with SD1 is $1.43 \%$.

\begin{tabular}{|c|c|c|c|c|c|c|c|c|c|}
\hline References & ILs crystals & Structures & Electrolytes & Dye & $\begin{array}{c}J_{S C} \\
(m A \\
\left.\mathrm{cm}^{-2}\right)\end{array}$ & $V_{O C}(m V)$ & $F F$ & $\eta(\%)$ & Durability \\
\hline $\begin{array}{l}\text { Midya et al., } \\
\text { (2010) }\end{array}$ & SD2 & & $\begin{array}{c}\mathrm{SD} 2 ; \mathrm{I}_{2} ; \\
\mathrm{Li}\left[\left(\mathrm{CF}_{3} \mathrm{SO}_{2}\right)_{2} \mathrm{~N}\right] ; \\
\mathrm{tBP} ; \mathrm{EMIB}(\mathrm{CN})_{4}\end{array}$ & N719 & 6.23 & 718 & 0.64 & 2.85 & N. A. \\
\hline
\end{tabular}

Table 4. Partial literature reported on the solid-state DSSCs with ILs conductors.

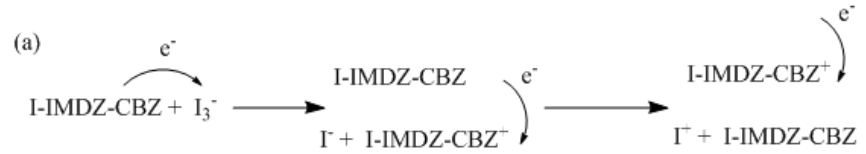

(b)

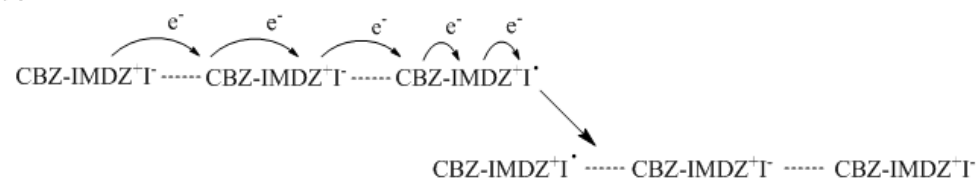

Figure 3. Schematic illustration of the mechanisms of (a) hole hopping and (b) iodine radical transport through CBZIMDZ-I solid-state ionic conductors [78].

\section{Summary and future prospects}

ILs are organic salts, composed mostly of organic ions that may undergo almost unlimited structural variations. Recently, the ILs act as useful electrolyte materials in DSSCs due to their negligible vapor pressure, high thermal stability, high ionic conductivity, and wide electrochemical window properties. This chapter mainly deals with the topic of novel ILs based electrolytes for solid-state DSSCs. The novel ILs based electrolytes include the IL-crystals (system A), IL-polymers (system B) and IL-conductors (system C).

Among system A, Chen et al. [57] have developed a novel solid-state electrolyte employing an ionic liquid crystal (DMPII) as CTI for DSSCs. An optimal cell efficiency of $5.87 \%$ can be obtained for the DSSC fabricated with the solid-state electrolyte of DMPII/KI/PEO. In system $\mathrm{B}$, an acidic IL polymer, P-HI, has been synthesized and employed in ILs electrolyte for DSSCs by Fang et al. [73]. The DSSC with the novel ILs electrolyte, containing P-HI, NMB, GuNCS, HMII and AMII, achieved a cell efficiency of $6.95 \%$. In the last system, Midya et al. [78] have designed and synthesized a new class of solid-state ionic conductor (SD2) based 
on a carbazole-imidazolium ionic salt as electrolytes for solid-state DSSCs. The DSSC with a solid-state electrolyte, containing SD2, $\mathrm{I}_{2}, \mathrm{Li}\left[\left(\mathrm{CF}_{3} \mathrm{SO}_{2}\right)_{2} \mathrm{~N}\right], \mathrm{tBP}$ and $\mathrm{EMIB}(\mathrm{CN})_{4}$, achieved a cell efficiency of $2.85 \%$. A literature survey on the solid-state DSSCs with IL-crystals, IL-polymers, and IL-conductors based electrolytes have shown that these systems possessed superior long-term durability over the traditional organic solvent based electrolytes.

Recently, the stable organic radical, 2,2,6,6-tetramethyl-1-piperidinyloxy (TEMPO), was demonstrated to be a promising redox system for DSSCs [80, 81], offering an alternative to the widely used iodide/triiodide couple. In the future, we can synthesize a novel IL with TEMPO-imidazole complex [82-84] for an iodine $\left(\mathrm{I}_{2}\right)$-free mediator system, and make application on solid-state DSSCs. This kind of TEMPO-imidazole complex containing TEMPO-redox radical and iodide-redox anion could potentially provide dual channels for charge transportation within the DSSCs.

\section{Acknowledgments}

This work was supported in part by the National Science Council of Taiwan under grant numbers NSC 100-2923-E-002-004-MY3 and NSC 100-2221-E-002-242-MY2.

\section{Author details}

Chuan-Pei Lee, Te-Chun Chu, Ling-Yu Chang, Jiang-Jen Lin and Kuo-Chuan Ho

National Taiwan University, Taipei, Taiwan

\section{References}

[1] Armaroli N, Balzani V. The future of energy supply: Challenges and opportunities. Angewandte Chemie - International Edition 2007,46:52-66.

[2] Gust D, Moore TA, Moore AL. Solar fuels via artificial photosynthesis. Accounts of Chemical Research 2009,42:1890-1898.

[3] Nocera DG. Chemistry of personalized solar energy. Inorganic Chemistry 2009,48:10001-10017.

[4] Yum JH, Baranoff E, Wenger S, Nazeeruddin MK, Grätzel M. Panchromatic engineering for dye-sensitized solar cells. Energy and Environmental Science 2011,4:842-857.

[5] O'Regan B, Grätzel M. A low-cost, high-efficiency solar cell based on dye-sensitized colloidal $\mathrm{TiO}_{2}$ films. Nature 1991,353:737-740. 
[6] Barbé CJ, Arendse F, Comte P, Jirousek M, Lenzmann F, Shklover V, et al. Nanocrystalline titanium oxide electrodes for photovoltaic applications. Journal of the American Ceramic Society 1997,80:3157-3171.

[7] Hagfeldt A, Grätzel M. Molecular photovoltaics. Accounts of Chemical Research 2000,33:269-277.

[8] Nazeeruddin MK, De Angelis F, Fantacci S, Selloni A, Viscardi G, Liska P, et al. Combined experimental and DFT-TDDFT computational study of photoelectrochemical cell ruthenium sensitizers. Journal of the American Chemical Society 2005,127:16835-16847.

[9] Gao F, Wang Y, Shi D, Zhang J, Wang M, Jing X, et al. Enhance the optical absorptivity of nanocrystalline $\mathrm{TiO}_{2}$ film with high molar extinction coefficient ruthenium sensitizers for high performance dye-sensitized solar cells. Journal of the American Chemical Society 2008,130:10720-10728.

[10] Chen CY, Wang M, Li JY, Pootrakulchote N, Alibabaei L, Ngoc-Le CH, et al. Highly efficient light-harvesting ruthenium sensitizer for thin-film dye-sensitized solar cells. ACS Nano 2009,3:3103-3109.

[11] Yella A, Lee HW, Tsao HN, Yi C, Chandiran AK, Nazeeruddin MK, et al. Porphyrinsensitized solar cells with cobalt (II/III)-based redox electrolyte exceed 12 percent efficiency. Science 2011,334:629-634.

[12] Armand M, Endres F, MacFarlane DR, Ohno H, Scrosati B. Ionic-liquid materials for the electrochemical challenges of the future. Nature Materials 2009,8:621-629.

[13] Earle MJ, Esperanca JMSS, Gilea MA, Canongia Lopes JN, Rebelo LPN, Magee JW, et al. The distillation and volatility of ionic liquids. Nature 2006,439:831-834.

[14] Stathatos E, Lianos P, Zakeeruddin SM, Liska P, Grätzel M. A quasi-solid-state dyesensitized solar cell based on a sol-gel nanocomposite electrolyte containing ionic liquid. Chemistry of Materials 2003,15:1825-1829.

[15] Kubo W, Murakoshi K, Kitamura T, Yoshida S, Haruki M, Hanabusa K, et al. Quasisolid-state dye-sensitized TiO 2 solar cells: Effective charge transport in mesoporous space filled with gel electrolytes containing iodide and iodine. Journal of Physical Chemistry B 2001,105:12809-12815.

[16] Mikoshiba S, Murai S, Sumino H, Hayase S. Anomalous increase in photocurrent density for quasi-solid dye sensitized solar cells by addition of tetra(bromomethyl)benzene. Chemistry Letters 2002:918-919.

[17] Wang P, Zakeeruddin SM, Exnar I, Grätzel M. High efficiency dye-sensitized nanocrystalline solar cells based on ionic liquid polymer gel electrolyte. Chemical Communications 2002,8:2972-2973. 
[18] Wang P, Zakeeruddin SM, Comte P, Exnar I, Grätzel M. Gelation of ionic liquidbased electrolytes with silica nanoparticles for quasi-solid-state dye-sensitized solar cells. Journal of the American Chemical Society 2003,125:1166-1167.

[19] Kubo W, Kambe S, Nakade S, Kitamura T, Hanabusa K, Wada Y, Yanagida, S. Photocurrent-determining processes in quasi-solid-state dye-sensitized solar cells using ionic gel electrolytes. Journal of Physical Chemistry B 2003,107:4374-4381.

[20] Haque SA, Tachibana Y, Willis RL, Moser JE, Grätzel M, Klug DR, Durrant, J. R. Parameters Influencing Charge Recombination Kinetics in Dye-Sensitized Nanocrystalline Titanium Dioxide Films. Journal of Physical Chemistry B 2000,104:538-547.

[21] Hara K, Horiguchi T, Kinoshita T, Sayama K, Arakawa H. Influence of electrolytes on the photovoltaic performance of organic dye-sensitized nanocrystalline $\mathrm{TiO}_{2}$ solar cells. Solar Energy Materials and Solar Cells 2001,70:151-161.

[22] Wagemaker M, Kentjens APM, Mulder FM. Equilibrium lithium transport between nanocrystalline phases in intercalated $\mathrm{TiO}_{2}$ anatase. Nature 2002,418:397-399.

[23] Kambe S, Nakade S, Kitamura T, Wada Y, Yanagida S. Influence of the electrolytes on electron transport in mesoporous $\mathrm{TiO}_{2}$-electrolyte systems. Journal of Physical Chemistry B 2002,106:2967-2972.

[24] Kumara GRA, Konno A, Shiratsuchi K, Tsukahara J, Tennakone K. Dye-sensitized solid-state solar cells: Use of crystal growth inhibitors for deposition of the hole collector. Chemistry of Materials 2002,14:954-955.

[25] Perera VPS, Pitigala PKDDP, Jayaweera PVV, Bandaranayake KMP, Tennakone K. Dye-Sensitized Solid-State Photovoltaic Cells Based on Dye Multilayer-Semiconductor Nanostructures. Journal of Physical Chemistry B 2003,107:13758-13761.

[26] Tennakone K, Kumara GRRA, Kottegoda IRM, Wijayantha KGU, Perera VPS. A solid-state photovoltaic cell sensitized with a ruthenium bipyridyl complex. Journal of Physics D: Applied Physics 1998,31:1492-1496.

[27] Bach U, Lupo D, Comte P, Moser JE, Weissörtel F, Salbeck J, Spreitzer, H., Grätzel, M. Solid-state dye-sensitized mesoporous $\mathrm{TiO}_{2}$ solar cells with high photon-to-electron conversion efficiencies. Nature 1998,395:583-585.

[28] Krüger J, Plass R, Cevey L, Piccirelli M, Grätzel M, Bach U. High efficiency solid-state photovoltaic device due to inhibition of interface charge recombination. Applied Physics Letters 2001,79:2085-2087.

[29] Krüger J, Plass R, Grätzel M, Matthieu HJ. Improvement of the photovoltaic performance of solid-state dye-sensitized device by silver complexation of the sensitizer cisbis $\left(4,4^{\prime}\right.$ - dicarboxy-2,2'bipyridine)-bis(isothiocyanato) ruthenium(II). Applied Physics Letters 2002,81:367-369. 
[30] Peter K, Wietasch H, Peng B, Thelakkat M. Dual-functional materials for interface modifications in solid-state dye-sensitised $\mathrm{TiO}_{2}$ solar cells. Applied Physics A: Materials Science and Processing 2004,79:65-71.

[31] Wu J, Hao S, Lan Z, Lin J, Huang M, Huang Y, Fang, L. Q., Yin, S., Sato, T. A thermoplastic gel electrolyte for stable quasi-solid-state dye-sensitized solar cells. Advanced Functional Materials 2007,17:2645-2652.

[32] Yang Y, Zhou Ch, Xu S, Hu H, Chen Bl, Zhang J, Wu, S. J., Liu, W., Zhao, X. Z. Improved stability of quasi-solid-state dye-sensitized solar cell based on poly (ethylene oxide)-poly (vinylidene fluoride) polymer-blend electrolytes. Journal of Power Sources 2008,185:1492-1498.

[33] Kubo W, Kitamura T, Hanabusa K, Wada Y, Yanagida S. Quasi-solid-state dye-sensitized solar cells using room temperature molten salts and a low molecular weight gelator. Chemical Communications 2002:374-375.

[34] Usui H, Matsui H, Tanabe N, Yanagida S. Improved dye-sensitized solar cells using ionic nanocomposite gel electrolytes. Journal of Photochemistry and Photobiology A: Chemistry 2004,164:97-101.

[35] Katakabe T, Kawano R, Watanabe M. Acceleration of redox diffusion and chargetransfer rates in an ionic liquid with nanoparticle addition. Electrochemical and SolidState Letters 2007,10:23-25.

[36] Lee KM, Chen PY, Lee CP, Ho KC. Binary room-temperature ionic liquids based electrolytes solidified with $\mathrm{SiO} 2$ nanoparticles for dye-sensitized solar cells. Journal of Power Sources 2009,190:573-577.

[37] Lee CP, Lee KM, Chen PY, Ho KC. On the addition of conducting ceramic nanoparticles in solvent-free ionic liquid electrolyte for dye-sensitized solar cells. Solar Energy Materials and Solar Cells 2009,93:1411-1416.

[38] Lee CP, Chen PY, Vittal R, Ho KC. Iodine-free high efficient quasi solid-state dyesensitized solar cell containing ionic liquid and polyaniline-loaded carbon black. Journal of Materials Chemistry 2010,20:2356-2361.

[39] Chen PY, Lee CP, Vittal R, Ho KC. A quasi solid-state dye-sensitized solar cell containing binary ionic liquid and polyaniline-loaded carbon black. Journal of Power Sources 2010,195:3933-3938.

[40] Chen Z, Yang H, Li X, Li F, Yi T, Huang C. Thermostable succinonitrile-based gel electrolyte for efficient, long-life dye-sensitized solar cells. Journal of Materials Chemistry 2007,17:1602-1607.

[41] Taguchi T, Zhang XT, Sutanto I, Tokuhiro KI, Rao TN, Watanabe H, Nakamori T, Uragami M, Fujishima A. Improving the performance of solid-state dye-sensitized solar cell using MgO-coated $\mathrm{TiO}_{2}$ nanoporous film. Chemical Communications 2003,9:2480-2481. 
[42] Pringle JM, Golding J, Forsyth CM, Deacon GB, Forsyth M, MacFarlane DR. Physical trends and structural features in organic salts of the thiocyanate anion. Journal of $\mathrm{Ma}$ terials Chemistry 2002,12:3475-3480.

[43] Wang P, Zakeeruddin SM, Moser JE, Grätzel M. A new ionic liquid electrolyte enhances the conversion efficiency of dye-sensitized solar cells. Journal of Physical Chemistry B 2003,107:13280-13285.

[44] Fredlake CP, Crosthwaite JM, Hert DG, Aki SNVK, Brennecke JF. Thermophysical properties of imidazolium-based ionic liquids. Journal of Chemical and Engineering Data 2004,49:954-964.

[45] Wang P, Zakeeruddin SM, Humphry-Baker R, Grätzel M. A binary ionic liquid electrolyte to achieve $\geq 7 \%$ power conversion efficiencies in dye-sensitized solar cells. Chemistry of Materials 2004,16:2694-2696.

[46] Wang P, Zakeeruddin SM, Moser JE, Humphry-Baker R, Grätzel M. A solvent-free, $\mathrm{SeCN}^{-} /(\mathrm{SeCN})_{3}{ }^{-}$based ionic liquid electrolyte for high-efficiency dye-sensitized nanocrystalline solar cells. Journal of the American Chemical Society 2004,126:7164-7165.

[47] Kuang D, Klein C, Zhang Z, Ito S, Moser JE, Zakeeruddin SM, Grätzel, M. Stable, high-efficiency ionic-liquid-based mesoscopic dye-sensitized solar cells. Small 2007,3:2094-2102.

[48] Jhong HR, Wong DSH, Wan CC, Wang YY, Wei TC. A novel deep eutectic solventbased ionic liquid used as electrolyte for dye-sensitized solar cells. Electrochemistry Communications 2009,11:209-211.

[49] Yamanaka N, Kawano R, Kubo W, Kitamura T, Wada Y, Watanabe M, Yanagida, S. Ionic liquid crystal as a hole transport layer of dye-sensitized solar cells. Chemical Communications 2005:740-742.

[50] Kawano R, Watanabe M. Equilibrium potentials and charge transport of an $\mathrm{I}^{-} / \mathrm{I}_{3}^{-}$redox couple in an ionic liquid. Chemical Communications 2003,9:330-331.

[51] Gordon CM, Holbrey JD, Kennedy AR, Seddon KR. Ionic liquid crystals: Hexafluorophosphate salts. Journal of Materials Chemistry 1998,8:2627-2636.

[52] Bradley AE, Hardacre C, Holbrey JD, Johnston S, McMath SEJ, Nieuwenhuyzent M. Small-angle $x$-ray scattering studies of liquid crystalline 1-alkyl-3-methylimidazolium salts. Chemistry of Materials 2002,14:629-635.

[53] Zhao Y, Zhai J, He J, Chen X, Chen L, Zhang L, Tian, Y., Jiang, L., Zhu, D. High-performance all-solid-state dye-sensitized solar cells utilizing imidazolium-type ionic crystal as charge transfer layer. Chemistry of Materials 2008,20:6022-6028.

[54] Lee CP, Lin LY, Chen PY, Vittal R, Ho KC. All-solid-state dye-sensitized solar cells incorporating SWCNTs and crystal growth inhibitor. Journal of Materials Chemistry 2010,20:3619-3625. 
[55] Lee C-P, Yeh M-H, Vittal R, Ho K-C. Solid-state dye-sensitized solar cell with a charge transfer layer comprising two ionic liquids and a carbon material. Journal of Materials Chemistry 2011,21:15471-15478.

[56] Armel V, Forsyth M, MacFarlane DR, Pringle JM. Organic ionic plastic crystal electrolytes; a new class of electrolyte for high efficiency solid state dye-sensitized solar cells. Energy E Environmental Science 2011,4:2234-2239.

[57] Chen J, Peng T, Fan K, Xia J. Iodine-free quasi solid-state dye-sensitized solar cells based on ionic liquid and alkali salt. Journal of Materials Chemistry 2011,21:16448-16452.

[58] Li Q, Chen X, Zhao J, Qiu L, Zhang Y, Sun B, Yan, F. Organic ionic plastic crystalbased electrolytes for solid-state dye-sensitized solar cells. Journal of Materials Chemistry 2012,22:6674-6679.

[59] Pringle JM, Howlett PC, MacFarlane DR, Forsyth M. Organic ionic plastic crystals: Recent advances. Journal of Materials Chemistry 2010,20:2056-2062.

[60] MacFarlane DR, Forsyth M. Plastic crystal electrolyte materials: New perspectives on solid state ionics. Advanced Materials 2001,13:957-966.

[61] Li Q, Zhao J, Sun B, Lin B, Qiu L, Zhang Y, Chen, X., Lu, J., Yan, F. High-temperature solid-state dye-sensitized solar cells based on organic ionic plastic crystal electrolytes. Advanced Materials 2012,24:945-950.

[62] Wang P, Dai Q, Zakeeruddin SM, Forsyth M, MacFarlane DR, Grätzel M. Ambient temperature plastic crystal electrolyte for efficient, all-solid-state dye-sensitized solar cell. Journal of the American Chemical Society 2004,126:13590-13591.

[63] Cao-Cen H, Zhao J, Qiu L, Xu D, Li Q, Chen X, Yan, F. High performance all-solidstate dye-sensitized solar cells based on cyanobiphenyl-functionalized imidazoliumtype ionic crystals. Journal of Materials Chemistry 2012,22:12842-12850.

[64] Sebastián N, De La Fuente MR, López DO, Pérez-Jubindo MA, Salud J, Diez-Berart S, Ros, M. B. Dielectric and thermodynamic study on the liquid crystal dimer $\alpha$-(4-cyanobiphenyl-4'-oxy)- $\omega$-(1-pyreniminebenzylidene-4'-oxy)undecane (CBO11O Py). Journal of Physical Chemistry B 2011,115:9766-9775.

[65] Vijayakumar G, Lee MJ, Song M, Jin SH, Lee JW, Lee CW, Gal, Y. S., Shim, H. J., Kang, Y., Lee, G. W., Kim, K., Park, N. G., Kim, S. New liquid crystal-embedded PVdF-co-HFP-based polymer electrolytes for dye-sensitized solar cell applications. Macromolecular Research 2009,17:963-968.

[66] Binnemans K. Ionic liquid crystals. Chemical Reviews 2005,105:4148-4204.

[67] Lammi RK, Fritz KP, Scholes GD, Barbara PF. Ordering of Single Conjugated Polymers in a Nematic Liquid Crystal Host. Journal of Physical Chemistry B 2004,108:4593-4596. 
[68] Wang G, Zhuo S, Wang L, Fang S, Lin Y. Mono-ion transport electrolyte based on ionic liquid polymer for all-solid-state dye-sensitized solar cells. Solar Energy 2012,86:1546-1551.

[69] Wang G, Wang L, Zhuo S, Fang S, Lin Y. An iodine-free electrolyte based on ionic liquid polymers for all-solid-state dye-sensitized solar cells. Chemical Communications 2011,47:2700-2702.

[70] Ohno H. Molten salt type polymer electrolytes. Electrochimica Acta 2001,46:1407-1411.

[71] Yoshizawa M, Ohno H. Synthesis of molten salt-type polymer brush and effect of brush structure on the ionic conductivity. Electrochimica Acta 2001,46:1723-1728.

[72] Ogihara W, Washiro S, Nakajima H, Ohno H. Effect of cation structure on the electrochemical and thermal properties of ion conductive polymers obtained from polymerizable ionic liquids. Electrochimica Acta 2006,51:2614-2619.

[73] Fang Y, Xiang W, Zhou X, Lin Y, Fang S. High-performance novel acidic ionic liquid polymer/ionic liquid composite polymer electrolyte for dye-sensitized solar cells. Electrochemistry Communications 2011,13:60-63.

[74] Chi WS, Koh JK, Ahn SH, Shin JS, Ahn H, Ryu DY, Kim, J. H. Highly efficient $\mathrm{I}_{2}$-free solid-state dye-sensitized solar cells fabricated with polymerized ionic liquid and graft copolymer-directed mesoporous film. Electrochemistry Communications 2011,13:1349-1352.

[75] Roh DK, Seo JA, Chi WS, Koh JK, Kim JH. Facile synthesis of size-tunable mesoporous anatase $\mathrm{TiO}_{2}$ beads using a graft copolymer for quasi-solid and all-solid dyesensitized solar cells. Journal of Materials Chemistry 2012,22:11079-11085.

[76] Chen X, Zhao J, Zhang J, Qiu L, Xu D, Zhang H, Han, X., Sun, B., Fu, G., Zhang, Y., Yan, F. Bis-imidazolium Based Poly(ionic liquid) Electrolytes for Quasi-Solid-State Dye-Sensitized Solar Cells. Journal of Materials Chemistry 2012.

[77] Chang Y-H, Lin P-Y, Huang S-R, Liu K-Y, Lin K-F. Enhancing photovoltaic performance of all-solid-state dye-sensitized solar cells by incorporating ionic liquid-physisorbed MWCNT. Journal of Materials Chemistry 2012,22:15592-15598.

[78] Midya A, Xie Z, Yang JX, Chen ZK, Blackwood DJ, Wang J, Adams, S., Loh, K. P. A new class of solid state ionic conductors for application in all solid state dye sensitized solar cells. Chemical Communications 2010,46:2091-2093.

[79] Ikeda N, Miyasaka T. A solid-state dye-sensitized photovoltaic cell with a poly(N-vinyl- carbazole) hole transporter mediated by an alkali iodide. Chemical Communications 2005:1886-1888.

[80] Nakahara K, Oyaizu K, Nishide H. Electrolyte anion-assisted charge transportation in poly(oxoammonium cation/nitroxyl radical) redox gels. Journal of Materials Chemistry 2012,22:13669-13673. 
[81] Zhang Z, Chen P, Murakami TN, Zakeeruddin SM, Grätzel M. The 2,2,6,6-Tetramethyl-1-piperidinyloxy Radical: An Efficient, Iodine- Free Redox Mediator for Dye-Sensitized Solar Cells. Advanced Functional Materials 2008,18:341-346.

[82] Suga T, Takeuchi S, Nishide H. Morphology-driven modulation of charge transport in radical/ion-containing, self-assembled block copolymer platform. Advanced Materials 2011,23:5545-5549.

[83] Strehmel V, Rexhausen H, Strauch P. 2,2,6,6-Tetramethylpiperidine-1-yloxyl bound to the imidazolium ion by an acetamido group for investigation of ionic liquids. Tetrahedron Letters 2010,51:747-750.

[84] Lee SH, Kim JK, Cheruvally G, Choi JW, Ahn JH, Chauhan GS, Song, C. E. Electrochemical properties of new organic radical materials for lithium secondary batteries. Journal of Power Sources 2008,184:503-507. 